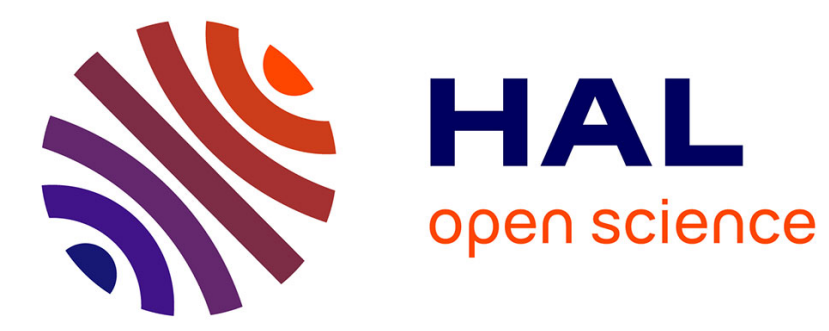

\title{
Introduction of water-solubilizing groups at the lower rim of tolylpyridine-bridged cavitands
}

\author{
Enrico Dalcanale, Laura Pirondini, Monica Melegari, Roberta Pinalli
}

\section{To cite this version:}

Enrico Dalcanale, Laura Pirondini, Monica Melegari, Roberta Pinalli. Introduction of watersolubilizing groups at the lower rim of tolylpyridine-bridged cavitands. Supramolecular Chemistry, 2007, 19 (01-02), pp.67-74. 10.1080/10610270600932826 . hal-00513487

\section{HAL Id: hal-00513487 \\ https://hal.science/hal-00513487}

Submitted on 1 Sep 2010

HAL is a multi-disciplinary open access archive for the deposit and dissemination of scientific research documents, whether they are published or not. The documents may come from teaching and research institutions in France or abroad, or from public or private research centers.
L'archive ouverte pluridisciplinaire $\mathbf{H A L}$, est destinée au dépôt et à la diffusion de documents scientifiques de niveau recherche, publiés ou non, émanant des établissements d'enseignement et de recherche français ou étrangers, des laboratoires publics ou privés. 


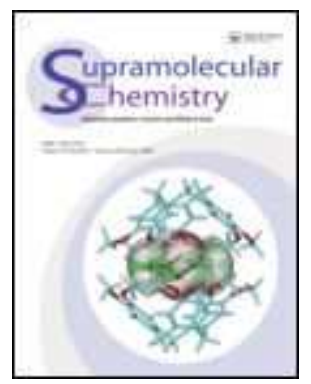

\section{Introduction of water-solubilizing groups at the lower rim of tolylpyridine-bridged cavitands}

\begin{tabular}{|r|l|}
\hline Journal: & Supramolecular Chemistry \\
\hline Manuscript ID: & GSCH-2006-0026.R1 \\
\hline Aunuscript Type: & Special Issue Paper \\
\hline Author: & 06-Jul-2006 \\
\hline $\begin{array}{l}\text { Complete List of Authors: } \\
\text { Keywords: }\end{array}$ & $\begin{array}{l}\text { Dalcanale, Enrico; University of Parma, Department of Organic and } \\
\text { Industrial Chemistry } \\
\text { Irondini, Laura; University of Parma, Department of Organic and } \\
\text { Industrial Chemistry } \\
\text { Industrial Chemistry } \\
\text { Pinalli, Roberta; University of Parma, Department of Organic and } \\
\text { Industrial Chemistry }\end{array}$ \\
\hline \begin{tabular}{l} 
water-soluble cavitands, resorcinarenes, coordination cages \\
\hline
\end{tabular} \\
\hline $\begin{array}{l}\text { Note: The following files were submitted by the author for peer review, but cannot be converted } \\
\text { to PDF. You must view these files (e.g. movies) online. }\end{array}$ \\
\hline $\begin{array}{l}\text { Scheme 1.cdx } \\
\text { Scheme 2.cdx } \\
\text { Scheme 3.cdx } \\
\text { Scheme 4.cdx } \\
\text { Scheme 5.cdx }\end{array}$ \\
\hline
\end{tabular}

\section{S) ScholaronE \\ Manuscript Central}




\title{
Introduction of water-solubilizing groups at the lower rim of tolylpyridine-bridged cavitands
}

\author{
LAURA PIRONDINI, MONICA MELEGARI, ROBERTA PINALLI and \\ ENRICO DALCANALE* \\ Dipartimento di Chimica Organica e Industriale, Università di Parma, Viale G.P. \\ Usberti 17/A, 43100 Parma, Italy
}

\begin{abstract}
In this paper we report the preparation of water-soluble methylene-bridged cavitands presenting either positively or negatively charged groups at the lower rim following three different synthetic routes. Moreover four anionic sulphate functions have been successfully inserted on a tolylpyridine-bridged cavitand in order to carry out the selfassembly of coordination cages in water.
\end{abstract}

Keywords: Resorcinarenes, Water-Soluble Cavitands, Coordination cages.

\footnotetext{
*Corresponding author. E-mail:enrico.dalcanale@ unipr.it
} 


\section{INTRODUCTION}

Water-soluble cavitands are interesting molecular receptors thanks to their versatile complexation abilities.[1, 2] In parallel, cavitands have been extensively studied as tetradentate ligands for the self-assembly of coordination cages in organic solvents.[3, 4] Water solubility of the coordination cages is an essential element to exploit the peculiar properties of their interiors. An outstanding example of watersoluble cavitand-based capsules, self-assembled through metal coordination, has been reported by the group of Harrison.[5, 6] Capsule formation and guest encapsulation are triggered by $\mathrm{pH}$ changes. The iminodiacetate ligands are attached to the cavitand upper rim and at the same time are responsible for the water solubility of the otherwise hydrophobic cavitand. Addition of cobalt (II) or iron (II) ions at $\mathrm{pH}>5$ results in the formation of the water soluble cages with the hydrophilic groups and metal ions positioned in the equatorial part of the cage.

An alternative strategy worth exploring, is to assemble cavitand-based coordination cages moving the water-solubilizing groups from the equatorial zone to the polar zone, as sketched in Figure 1. This requires incorporating the water-solubilizing groups at the lower rim of the cavitand tetradentate ligand, leaving the upper apical and bridge positions free for ligand introduction. In our case the ligands responsible for metal coordination are tolylpyridine bridging units appended to the upper rim[3, 7] as separate entities from the hydrophilic groups. By adding two equivalents of a suitable metal precursor to a water solution of these cavitands it would be possible to assemble a water-soluble nanosized cage directly in aqueous solution (Figure 1).

Water soluble cavitands bearing charged groups at the lower rim have been described in the literature. The water-solubilizing groups chosen were ammonium salts, [ 8 ] 
phosphates,[9] and carboxylates.[10] All these cavitands have been synthesized from a common precursor, the hydroxyl-footed resorcinarene 9.[11]

In this paper we report the preparation of water-soluble methylene-bridged cavitands presenting either positively $\left(\mathrm{NH}_{3}{ }^{+}, \mathbf{4 b}, \mathbf{7 b}\right)$ or negatively charged groups $\left(\mathrm{OSO}_{3}^{-}, \mathbf{1 4}\right)$ at the lower rim, the synthesis of the tetradentate cavitand ligand $\mathbf{1 5}$ having four sulphate feet and attempts to form the corresponding coordination cages.

\section{Figure 1.}

In order to work out the best synthetic conditions for the introduction of the charged groups at the lower rim, we synthesised the methylene-bridged cavitands $\mathbf{1 ,} \mathbf{5}$ and $\mathbf{1 3}$ as model compounds by applying the method reported by Kaifer for the bridging reaction.[12] For the introduction of the positively charged ammonium groups two different strategies were attempted, as reported in Schemes 1 and 2. Both gave the desired compounds $4 \mathbf{a}$ and $7 \mathbf{a}$ which turned out to be completely water soluble under acidic conditions. In the procedure of Scheme 1 the lower rim hydroxyls of $\mathbf{1}$ were converted to $\mathrm{NH}_{2}$ groups with a $33 \%$ overall yield. Specifically, the azide derivative 3 was prepared following a synthetic procedure reported by Rebek et al. [8] by mesylation of 1 with $\mathrm{MsCl}\left(\mathrm{Et}_{3} \mathrm{~N}, \mathrm{CH}_{2} \mathrm{Cl}_{2}, 91 \%\right)$ and further treatment with $\mathrm{NaN}_{3}$ in DMF at $70{ }^{\circ} \mathrm{C}$ (52\% yield). The one-pot reduction of 3 using $\mathrm{PPh}_{3}$ in $\mathrm{THF} / \mathrm{H}_{2} \mathrm{O}$ at $70{ }^{\circ} \mathrm{C}$ resulted in cavitand $\mathbf{4 a}$ which was then transformed in the tetraammonium salt $\mathbf{4 b}$ in acidic water $(10 \%$ aq. $\mathrm{HCl})$ (Scheme 1). The resulting cavitand is water-soluble. 


\section{Scheme 1}

Alternatively, 5, having four bromo substituents in the apical positions, was submitted to Mitsunobu reaction with phthalimide, diethyl azodicarboxylate (DEAD), and $\mathrm{PPh}_{3}$ in THF (78\% yield) followed by the Gabriel reaction with hydrazine in ethanol $(92 \%$ yield) resulting in tetraamine functionalized cavitand 7a, whose ammonium salt is completely soluble in $\mathrm{H}_{2} \mathrm{O}$ (Scheme 2). This second procedure gave an overall yield of $72 \%$ from $\mathbf{5}$, more than doubled if compared to the overall yield of the first synthetic pathway $(33 \%)$.

\section{Scheme 2}

For this reason the Mitsunobu-Gabriel reaction was selected as the chosen method for the synthesis of the tolylpyridine-bridged cavitand $\mathbf{1 2}$ with four amine at the lower rim (Scheme 3). The synthesis of the hydroxyl-footed tetradentate cavitand $\mathbf{1 0}$ was performed by bridging the corresponding resorcinarene 9 with dibromotolylpyridine in dry DMA at $80{ }^{\circ} \mathrm{C}(30 \%$ yield $)$. Then, as in the previous case, the hydroxyls were converted into phthalimide groups giving cavitand $\mathbf{1 1}$ with a $31 \%$ yield. The subsequent reaction with hydrazine in ethanol resulted in the desired tetraamine cavitand $\mathbf{1 2}(85 \%$ yield). Unaccountably, the following step of salification in $10 \%$ aqueous $\mathrm{HCl}$ to give the corresponding water soluble tetrammonium salt failed. The $\mathrm{HCl}$ added caused the breaking of the tolylpyridine bridges as demonstrated by the recovery of the corresponding tolylpyridine aldehyde and tetraamine resorcinarene in the aqueous solution. In fact ESI-MS spectrometry showed the presence of two prominent peaks at 
184 and $717 \mathrm{~m} / \mathrm{z}$ due to these two compounds. Water-solubility through acidification of the amine groups at the lower rim cannot be applied to the case of our tetradentate cavitand ligand, due to the reactivity of the benzal-type bridges. For this reason the introduction of positively charged ammonium groups at the lower rim is not a valuable strategy for the construction of water-soluble pyridyl tetradentate ligands.

\section{Scheme 3}

The second approach to the introduction of hydrophilic groups at the lower rim of tetradentate cavitands was through the functionalization with sulphate anions. Once again the first synthetic effort has been focused on the synthesis of the methylenebridged cavitand as model compound. At first the synthesis of tetrasulphonate water soluble resorcinarenes reported by Aoyama[13] was attempted, but the following bridging reaction failed due to the presence of the sulphonate groups.

For this reason we moved to another strategy: the introduction of the hydrophilic sulphate groups on a preformed cavitand. In a recent article, Linhardt,[14] reported an interesting way to functionalize sugars with sulphate groups in order to increase their solubility in water. This method consists in the sulphonation of the $\mathrm{OH}$ groups using $\mathrm{NMe}_{3} \cdot \mathrm{SO}_{3}$ in DMF at $50{ }^{\circ} \mathrm{C}$. Cavitand $\mathbf{1 3}$ was therefore combined with sulphur trioxide trimethylamine complex giving the water soluble tetrasulphate cavitand $\mathbf{1 4}$ with a $65 \%$ yield (Scheme 4).

\section{Scheme 4}


The success of this approach on the model compound encouraged us to follow the same protocol on tolylpyridine-bridged cavitand 10 which was reacted with $\mathrm{NMe}_{3} \bullet \mathrm{SO}_{3}$ as previously described (Scheme 5).

\section{Scheme 5}

The insertion of the four sodium sulphate groups was successful as confirmed by ESIMS and ${ }^{1} \mathrm{H}-\mathrm{NMR}$ analyses. Unfortunately cavitand $\mathbf{1 5}$ is not soluble in water, since the presence of four tolylpyridine groups as bridging units make the hydrophobic part of the molecule predominant despite of the presence of four charged sulphate salts. Cavitand 15 is soluble in water/alcohol and water/DMSO mixtures.

As already proven by Fujita, water solubility is not strictly necessary for the organic ligands if the metal precursor is sufficiently hydrophilic to make the resulting nanosize cage water-soluble.[15] Cavitand $\mathbf{1 5}$ was therefore tested for the self-assembly of the corresponding coordination cage in the presence of $\mathrm{Pd}(\mathrm{en})\left(\mathrm{NO}_{3}\right)_{2}$, exploiting the eight nitrate counterions to promote the water solubility of the cage.

The self-assembly led to the formation of insoluble precipitates. The outcome is the same either starting from a homogeneous solution (DMSO) or from a cavitand $\mathbf{1 5}$ suspension in water. Different working temperatures do not change the situation. At this stage of the work we can only speculate about the failure of cage self-assembly. Our hypothesis is the following: the $\mathrm{R}-\mathrm{O}-\mathrm{SO}_{3}{ }^{-}$groups displace the counterions of the metal precursor interfering with the self-assembly process.[16] 


\section{CONCLUSIONS}

In summary, three different synthetic routes to obtain water soluble methylene-bridged cavitands have been reported.

In the case of the tolylpyridine-bridged cavitands, acidification with $10 \%$ aqueous $\mathrm{HCl}$ of tetraamine-footed cavitand $\mathbf{1 2}$ led to the breaking of the bridging ligand groups, thus precluding the following step of cage self-assembly. On the other hand the insertion of four anionic sulphate functions on the same tetradentate cavitand turned out to be synthetically viable, but not sufficient to promote the solubility of the cavitand in water. Water-solubility in these type of cavitands is heavily dependent on the size of the hydrophobic bridging units. Cage self-assembly has shown to be inhibited by the presence of anionic groups at the lower rim.

\section{EXPERIMENTAL}

General methods: All commercial reagents were ACS grade and used as received. All solvents were dried over 3 and 4 A molecular sieves. ${ }^{1}$ H NMR spectra were recorded on Bruker AC300 (300 MHz), Avance (300 MHz) and AMX400 (400 MHz) spectrometers and all chemical shifts $(\delta)$ were reported in parts per million (ppm) in relation to the proton resonances which resulted from incomplete deuteration of the NMR solvents. Mass spectra of the organic compounds were measured with a Finnigan MAT SSQ710 spectrometer, using the CI (chemical ionization) technique. Electrospray ionization mass spectrometry (ESI-MS) experiments were performed on a Waters ZMD spectrometer equipped with an electrospray interface. Matrix-assisted laser desorption ionization time-of-flight (MALDI-TOF) mass spectra were obtained on a PerSpective 
Biosystems Voyager DERP spectrometer equipped with delayed extraction. Column chromatography was performed by using silica gel 60 (Merck 70-230 mesh).

Cavitands 1,[9] 5 and 13,[17] and 4,4'-(a,a'-dibromo)tolylpyridine 8,[7] were prepared according to literature procedures.

Cavitand 2: Methanesulfonylchloride $(25 \mu \mathrm{L}, 0.320 \mathrm{mmol})$ was added drop by drop to a stirred solution of 1 (56 mg, $0.067 \mathrm{mmol})$ in $\mathrm{CH}_{2} \mathrm{Cl}_{2}(10 \mathrm{~mL})$ and $\mathrm{Et}_{3} \mathrm{~N}(0.12 \mathrm{~mL}$, $0.870 \mathrm{mmol}$ ) at $0^{\circ} \mathrm{C}$. After $3 \mathrm{~h}$, of stirring at $0^{\circ} \mathrm{C}$, the solution was poured into $10 \%$ aq. $\mathrm{HCl}$. The aqueous layer was extracted with $\mathrm{CH}_{2} \mathrm{Cl}_{2}$. The organic layer was washed with aqueous $\mathrm{NaHCO}_{3}$ solution and concentrated to obtain the corresponding cavitand 2 (69 mg, $91 \%)$.

${ }^{1} \mathrm{H}$ NMR $\left(\mathrm{CDCl}_{3}, 300 \mathrm{MHz}\right): \delta=7.05\left(\mathrm{~s}, 4 \mathrm{H}, \mathrm{Ar} H_{\text {down }}\right) ; 5.86\left(\mathrm{~d}, 4 \mathrm{H}, \mathrm{OCH}_{\text {out }} \mathrm{O},{ }^{2} \mathrm{~J}=7.0\right.$ $\mathrm{Hz}) ; 4.79\left(\mathrm{t}, 4 \mathrm{H}, \operatorname{ArCH},{ }^{3} \mathrm{~J}=8.0 \mathrm{~Hz}\right) ; 4.36\left(\mathrm{t}, 8 \mathrm{H}, \mathrm{CH}_{2} \mathrm{OMs},{ }^{3} \mathrm{~J}=6.3 \mathrm{~Hz}\right) ; 4.26(\mathrm{~d}, 4 \mathrm{H}$, $\left.\mathrm{OCH}_{\text {in }} \mathrm{O},{ }^{2} \mathrm{~J}=7.0 \mathrm{~Hz}\right) ; 2.95\left(\mathrm{~s}, 12 \mathrm{H}, \mathrm{CH}_{3} \mathrm{~S}\right) ; 2.39\left(\mathrm{~m}, 8 \mathrm{H}, \mathrm{ArCHCH}_{2}\right) ; 1.96(\mathrm{~s}, 12 \mathrm{H}$, $\left.\mathrm{ArCH}_{3}\right) ; 1.79\left(\mathrm{~m}, 8 \mathrm{H}, \mathrm{CH}_{2} \mathrm{CH}_{2} \mathrm{CH}_{2}\right)$.

MALDI TOF-MS (m/z): $1161[\mathrm{M}+\mathrm{Na}]^{+}$.

Cavitand 3: To a solution of $2(69 \mathrm{mg}, 0.060 \mathrm{mmol})$ in DMF (2 mL) was added $\mathrm{NaN}_{3}$ (23 $\mathrm{mg}, 0.350 \mathrm{mmol}$ ) and the mixture was stirred for $24 \mathrm{~h}$ at $70^{\circ} \mathrm{C}$. After, the reaction mixture was poured into aqueous $\mathrm{Na}_{2} \mathrm{CO}_{3}$, and the formed precipitate was filtered, washed with water and dried to give $3(29 \mathrm{mg}, 52 \%)$.

${ }^{1} \mathrm{H}$ NMR $\left(\mathrm{CDCl}_{3}, 300 \mathrm{MHz}\right): \delta=6.96\left(\mathrm{~s}, 4 \mathrm{H}, \mathrm{ArH}_{\text {down }}\right) ; 5.88\left(\mathrm{~d}, 4 \mathrm{H}, \mathrm{OCH}_{\text {out }} \mathrm{O},{ }^{2} \mathrm{~J}=7.4\right.$ $\mathrm{Hz}) ; 4.79$ (br t, $4 \mathrm{H}, \mathrm{ArCH}$ ); $4.24\left(\mathrm{~d}, 4 \mathrm{H}, \mathrm{OCH}_{i n} \mathrm{O},{ }^{2} \mathrm{~J}=7.4 \mathrm{~Hz}\right) ; 3.42$ (br t, $8 \mathrm{H}, \mathrm{CH}_{2} \mathrm{~N}_{3}$ ); $2.32\left(\mathrm{~m}, 8 \mathrm{H}, \mathrm{ArCHCH}_{2}\right) ; 1.96\left(\mathrm{~s}, 12 \mathrm{H}, \mathrm{ArCH}_{3}\right) ; 1.66\left(\mathrm{~m}, 8 \mathrm{H}, \mathrm{CH}_{2} \mathrm{CH}_{2} \mathrm{CH}_{2}\right)$. 
CI-MS (m/z): $925[\mathrm{M}]^{+}, 898\left[\mathrm{M}-\mathrm{N}_{2}\right]^{+}$.

Cavitand 4b: $\mathrm{PPh}_{3}(83 \mathrm{mg}, 0.317 \mathrm{mmol})$ was added to a solution of $\mathbf{3}(29 \mathrm{mg}, 0.032$ mmol) in THF ( $2 \mathrm{~mL})$ and water $(40 \mu \mathrm{L}, 2.220 \mathrm{mmol})$. The mixture was stirred for $2 \mathrm{~h}$ at $70^{\circ} \mathrm{C}$ and then poured into aqueous $\mathrm{Na}_{2} \mathrm{CO}_{3}$. The aqueous layer was extracted with EtOAc and the organic layer was concentrated in vacuo to give $\mathbf{4 a}(23 \mathrm{mg}, 88 \%)$. The free amine $4 \mathbf{a}$ was converted into the corresponding tetraammonium salt $\mathbf{4 b}$ by using $10 \%$ aq. $\mathrm{HCl}$.

${ }^{1} \mathrm{H}$ NMR $\left(\mathrm{D}_{2} \mathrm{O}, 300 \mathrm{MHz}\right): \delta=7.38\left(\mathrm{~s}, 4 \mathrm{H}, \operatorname{Ar} H_{\text {down }}\right) ; 5.87\left(\mathrm{~d}, 4 \mathrm{H}, \mathrm{OCH}_{\text {out }} \mathrm{O},{ }^{2} \mathrm{~J}=7.4\right.$ $\mathrm{Hz}) ; 4.61\left(\mathrm{t}, 4 \mathrm{H}, \operatorname{ArCH},{ }^{3} \mathrm{~J}=8.1 \mathrm{~Hz}\right) ; 4.09\left(\mathrm{~d}, 4 \mathrm{H}, \mathrm{OCH}_{\text {in }} \mathrm{O},{ }^{2} \mathrm{~J}=7.4 \mathrm{~Hz}\right) ; 3.02(\mathrm{t}, 8 \mathrm{H}$, $\left.\mathrm{CH}_{2} \mathrm{NH}_{2},{ }^{3} \mathrm{~J}=7.5 \mathrm{~Hz}\right) ; 2.47\left(\mathrm{~m}, 8 \mathrm{H}, \mathrm{ArCHCH}_{2}\right) ; 1.82\left(\mathrm{~s}, 12 \mathrm{H}, \mathrm{ArCH}_{3}\right) ; 1.58(\mathrm{~m}, 8 \mathrm{H}$, $\mathrm{CH}_{2} \mathrm{CH}_{2} \mathrm{CH}_{2}$ ).

4a: ESI-MS (m/z): $823[\mathrm{M}+\mathrm{H}]^{+}, 412[\mathrm{M}+2 \mathrm{H}]^{2+}$.

4b: $\mathrm{C}_{48} \mathrm{H}_{64} \mathrm{Cl}_{4} \mathrm{~N}_{4} \mathrm{O}_{8}$ (966.86): calcd. C 59.63, H 6.67, N 5.79; found C 59.23, H 6.74, N 5.66.

Cavitand 6: Phthalimide $(120 \mathrm{mg}, 0.815 \mathrm{mmol}), \mathrm{PPh}_{3}(213 \mathrm{mg}, 0.812 \mathrm{mmol})$ and DEAD (257 mg, $1.475 \mathrm{mmol})$ were added to a solution of 5 (200 $\mathrm{mg}, 0.184 \mathrm{mmol})$ in dry THF $(60 \mathrm{~mL})$. The mixture was refluxed for 5 days. The reaction was quenched in brine $(30 \mathrm{~mL})$ and the aqueous solution extracted with $\mathrm{CH}_{2} \mathrm{Cl}_{2}$. The organic layer was concentrated in vacuo, and the residue was recrystalized from $\mathrm{CH}_{2} \mathrm{Cl}_{2}$ and $\mathrm{EtOH}$ to give $6(230 \mathrm{mg}, 78 \%)$.

${ }^{1} \mathrm{H}$ NMR $\left(\mathrm{CDCl}_{3}, 300 \mathrm{MHz}\right): \delta=7.73\left(\mathrm{~m}, 8 \mathrm{H}, H_{F t}\right) ; 7.59\left(\mathrm{~m}, 8 \mathrm{H}, H_{F t}\right) ; 7.18(\mathrm{~s}, 4 \mathrm{H}$, $\left.\operatorname{Ar} H_{\text {down }}\right) ; 5.92\left(\mathrm{~d}, 4 \mathrm{H}, \mathrm{OC} H_{\text {out }} \mathrm{O},{ }^{2} \mathrm{~J}=7.4 \mathrm{~Hz}\right) ; 4.89\left(\mathrm{t}, 4 \mathrm{H}, \operatorname{ArCH},{ }^{3} \mathrm{~J}=8.0 \mathrm{~Hz}\right) ; 4.36(\mathrm{~d}$, 
$\left.4 \mathrm{H}, \mathrm{OCH}_{\text {in }} \mathrm{O},{ }^{2} \mathrm{~J}=7.4 \mathrm{~Hz}\right) ; 3.91\left(\mathrm{t}, 8 \mathrm{H}, \mathrm{CH}_{2} \mathrm{~N},{ }^{3} \mathrm{~J}=7.2 \mathrm{~Hz}\right) ; 2.42\left(\mathrm{~m}, 8 \mathrm{H}, \operatorname{ArCHCH}_{2}\right)$; 1.79 (m, 8H, $\mathrm{CH}_{2} \mathrm{CH}_{2} \mathrm{CH}_{2}$ ).

CI-MS (m/z): $1602[\mathrm{M}+\mathrm{H}]^{+}$.

Cavitand 7a: To the solution of $6(200 \mathrm{mg}, 0.125 \mathrm{mmol})$ in EtOH $(10 \mathrm{~mL})$ was added hydrazine hydrate $(7.3 \mathrm{~mL}, 0.149 \mathrm{~mol})$ and the mixture was refluxed under nitrogen atmosphere for $3 \mathrm{~h}$. The EtOH was evaporated and the residue taken up in $20 \mathrm{~mL}$ of $2 \mathrm{~N}$ aqueous $\mathrm{KOH}$ solution. The basic solution was extracted with $\mathrm{CH}_{2} \mathrm{Cl}_{2}$. The organic layer was washed with brine, dried, and concentrated in vacuo to give 7a (125 mg, $92 \%)$

${ }^{1} \mathrm{H}$ NMR $\left(\mathrm{CDCl}_{3}, 600 \mathrm{MHz}\right): \delta=7.16\left(\mathrm{~s}, 4 \mathrm{H}, \mathrm{ArH}_{\text {down }}\right) ; 5.95\left(\mathrm{~d}, 4 \mathrm{H}, \mathrm{OCH}_{\text {out }} \mathrm{O},{ }^{2} \mathrm{~J}=7.2\right.$ $\mathrm{Hz}) ; 4.84\left(\mathrm{t}, 4 \mathrm{H}, \operatorname{ArCH},{ }^{3} \mathrm{~J}=7.8 \mathrm{~Hz}\right) ; 4.38\left(\mathrm{~d}, 4 \mathrm{H}, \mathrm{OCH}_{i n} \mathrm{O},{ }^{2} \mathrm{~J}=7.2 \mathrm{~Hz}\right) ; 2.80(\mathrm{br} \mathrm{t}, 8 \mathrm{H}$, $\mathrm{CH}_{2} \mathrm{NH}_{2}$ ); 2.32 (br t, $\left.8 \mathrm{H}, \mathrm{ArCHCH}_{2}\right) ; 1.46\left(\mathrm{~m}, 8 \mathrm{H}, \mathrm{CH}_{2} \mathrm{CH}_{2} \mathrm{CH}_{2}\right.$ ).

CI-MS (m/z): $1082[\mathrm{M}+\mathrm{H}]^{+}$.

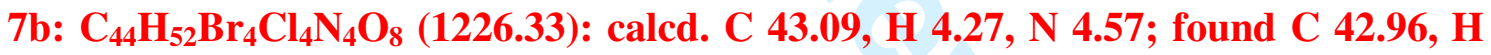
4.42, $\mathbf{N} 4.46$.

Cavitand 10: $1.580 \mathrm{~g}(4.83 \mathrm{mmol})$ of 4,4'-(a,a'-dibromo)tolylpyridine $\mathbf{8}$ and $1.150 \mathrm{~g}$ (8.28 mmol) of $\mathrm{K}_{2} \mathrm{CO}_{3}$ were added under nitrogen to a solution of $0.500 \mathrm{~g}(0.69 \mathrm{mmol})$ of resorcinarene 9 in dry DMA $(25 \mathrm{~mL})$. The mixture was stirred in a sealed tube at $80^{\circ} \mathrm{C}$ for $48 \mathrm{~h}$. The reaction was quenched by water addition $(10 \mathrm{~mL})$ and the formed precipitate was filtered. The black crude obtained was purified by column chromatography $\left(\mathrm{SiO}_{2}, \mathrm{CH}_{2} \mathrm{Cl}_{2} /\right.$ Ethanol 9:1) to give compound $\mathbf{1 0}$ as a yellow solid $(0.302 \mathrm{~g}, 30 \%)$ 
${ }^{1} \mathrm{H}$ NMR ([D $]$ DMSO, $\left.400 \mathrm{MHz}\right): \delta=8.65\left(\mathrm{~d}, 8 \mathrm{H}, \mathrm{XX}\right.$ ' part of system $\mathrm{AA}^{\prime} \mathrm{XX}$, $\left.H_{o P y}{ }^{3} \mathrm{~J}=4.8 \mathrm{~Hz}\right) ; 7.90\left(\mathrm{~d}, 8 \mathrm{H}, \mathrm{BB}^{\prime}\right.$ part of system AA'BB', $\left.{ }^{3} \mathrm{~J}=8.0 \mathrm{~Hz}\right) ; 7.86(\mathrm{~d}, 8 \mathrm{H}$, $\mathrm{AA}^{\prime}$ part of system AA'BB', $\left.{ }^{3} \mathrm{~J}=8.0 \mathrm{~Hz}\right) ; 7.82\left(\mathrm{~s}, 4 \mathrm{H}, \mathrm{Ar} H_{\text {down }}\right) ; 7.70\left(\mathrm{~d}, 8 \mathrm{H}, \mathrm{AA}^{\prime}\right.$ part of system AA'XX', $\left.H_{m P y},{ }^{3} \mathrm{~J}=4.8 \mathrm{~Hz}\right) ; 6.96\left(\mathrm{~s}, 4 \mathrm{H}, \mathrm{Ar} H_{u p}\right) ; 5.58(\mathrm{~s}, 4 \mathrm{H}, \mathrm{OCHO}) ; 4.82(\mathrm{t}$, $\left.4 \mathrm{H}, \mathrm{ArCH},{ }^{3} \mathrm{~J}=8.0 \mathrm{~Hz}\right) ; 4.51\left(\mathrm{t}, 4 \mathrm{H}, \mathrm{CH}_{2} \mathrm{OH},{ }^{3} \mathrm{~J}=4.8 \mathrm{~Hz}\right) ; 3.58\left(\mathrm{~m}, 8 \mathrm{H}, \mathrm{CH}_{2} \mathrm{OH}\right) ; 2.55$ (m, 8H, $\mathrm{ArCHCH}$ ); 1.54 (m, 8H, $\mathrm{CH}_{2} \mathrm{CH}_{2} \mathrm{CH}_{2}$ ).

CI-MS (m/z): $1381[\mathrm{M}+\mathrm{H}]^{+}$.

Cavitand 11: Phthalimide (38 mg, $0.261 \mathrm{mmol}), \mathrm{PPh}_{3}(68 \mathrm{mg}, 0.261 \mathrm{mmol})$ and DEAD (83 mg, $0.475 \mathrm{mmol})$ were added to a solution of $\mathbf{1 0}(82 \mathrm{mg}, 0.059 \mathrm{mmol})$ in dry THF (20 mL). On the second and sixth day, an additional portion of phthalimide (38 $\mathrm{mg}$ ), $\mathrm{PPh}_{3}(68 \mathrm{mg})$ and DEAD $(83 \mathrm{mg})$ was added to the mixture. The reaction was refluxed for 8 days, quenched in brine $(30 \mathrm{~mL})$ and the aqueous solution extracted with diethyl ether. The organic layer was concentrated in vacuo, and the crude product obtained was purified by column chromatography $\left(\mathrm{SiO}_{2}, \mathrm{CH}_{2} \mathrm{Cl}_{2} / \mathrm{EtOAc} 7: 3, \mathrm{CH}_{2} \mathrm{Cl}_{2} / \mathrm{EtOH} 8: 2\right)$ to give compound $\mathbf{1 1}$ (35 mg, 31\%).

${ }^{1} \mathrm{H}$ NMR $\left(\mathrm{CDCl}_{3}, 600 \mathrm{MHz}\right): \delta=8.68\left(\mathrm{bd}, 8 \mathrm{H}, \mathrm{XX}\right.$ ' part of system AA'XX', $\left.H_{o P y}\right)$; 7.82 (bd, 8H, BB' part of system AA'BB'); $7.73\left(\mathrm{bd}, 8 \mathrm{H}, H_{P h t}\right) ; 7.70\left(\mathrm{bd}, 8 \mathrm{H}, \mathrm{AA}^{\prime}\right.$ part of system AA'BB'); $7.64\left(\mathrm{bd}, 8 \mathrm{H}, H_{P h t}\right) ; 7.59\left(\mathrm{bd}, 8 \mathrm{H}, \mathrm{AA}^{\prime}\right.$ part of system AA'XX', $\left.H_{m P y}\right) ; 7.46\left(\mathrm{~s}, 4 \mathrm{H}, \mathrm{Ar} H_{d o w n}\right) ; 6.72\left(\mathrm{~s}, 4 \mathrm{H}, \mathrm{Ar} H_{u p}\right) ; 5.55(\mathrm{~s}, 4 \mathrm{H}, \mathrm{OCHO}) ; 5.02(\mathrm{t}, 4 \mathrm{H}$, $\left.\operatorname{ArCH},{ }^{3} \mathrm{~J}=7.8 \mathrm{~Hz}\right) ; 4.00\left(\mathrm{t}, 8 \mathrm{H}, \mathrm{CH}_{2} \mathrm{~N},{ }^{3} \mathrm{~J}=7.2 \mathrm{~Hz}\right) ; 2.61\left(\mathrm{~m}, 8 \mathrm{H}, \operatorname{ArCHCH}_{2}\right) ; 1.90(\mathrm{~m}$, $8 \mathrm{H}, \mathrm{CH}_{2} \mathrm{CH}_{2} \mathrm{CH}_{2}$ ).

CI-MS (m/z): $1898[\mathrm{M}]^{+}, 1753$ [M-Pht $]^{+}, 1607$ [M-2Pht] $]^{+}$ 
Cavitand 12: To the solution of 11 (35 mg, $0.018 \mathrm{mmol})$ in $\mathrm{EtOH}(5 \mathrm{~mL})$ hydrazine hydrate $(14 \mathrm{~mL}, 0.221 \mathrm{~mol})$ was added and the mixture was refluxed under nitrogen atmosphere for $3 \mathrm{~h}$. The EtOH was evaporated and the residue taken up in $10 \mathrm{~mL}$ of $2 \mathrm{~N}$ aqueous $\mathrm{KOH}$ solution. The basic solution was extracted with $\mathrm{CH}_{2} \mathrm{Cl}_{2}$. The organic layer was washed with brine, dried, and concentrated in vacuo to give $\mathbf{1 2}$ (22 $\mathrm{mg}, 85 \%)$. ${ }^{1} \mathrm{H}$ NMR $\left(\mathrm{CDCl}_{3}, 300 \mathrm{MHz}\right): \delta=8.67\left(\mathrm{bd}, 8 \mathrm{H}, \mathrm{XX}\right.$ ' part of system $\left.\mathrm{AA}^{\prime} \mathrm{XX}{ }^{\prime}, H_{o P y}\right)$; $7.81\left(\mathrm{~d}, 8 \mathrm{H}, \mathrm{BB}^{\prime}\right.$ part of system AA'BB', $\left.{ }^{3} \mathrm{~J}=8.3 \mathrm{~Hz}\right) ; 7.71\left(\mathrm{~d}, 8 \mathrm{H}, \mathrm{AA}^{\prime}\right.$ part of system $\left.\mathrm{AA}^{\prime} \mathrm{BB}^{\prime},{ }^{3} \mathrm{~J}=8.3 \mathrm{~Hz}\right) ; 7.50\left(\mathrm{bd}, 8 \mathrm{H}, \mathrm{AA}^{\prime}\right.$ part of system AA'XX', $\left.H_{m P y}\right) ; 7.33(\mathrm{~s}, 4 \mathrm{H}$, $\left.\operatorname{Ar} H_{\text {down }}\right) ; 6.74\left(\mathrm{~s}, 4 \mathrm{H}, \mathrm{Ar} H_{\text {up }}\right) ; 5.57$ (s, 4H, OCHO); 4.98 (bt, 4H, $\left.\operatorname{ArCH}\right) ; 3.71(\mathrm{~m}, 8 \mathrm{H}$, $\left.\mathrm{CH}_{2} \mathrm{NH}_{2},{ }^{3} \mathrm{~J}=7.0 \mathrm{~Hz}\right) ; 2.89\left(\mathrm{~m}, 8 \mathrm{H}, \mathrm{ArCHCH}_{2}\right) ; 1.61\left(\mathrm{~m}, 8 \mathrm{H}, \mathrm{CH}_{2} \mathrm{CH}_{2} \mathrm{CH}_{2}\right)$. MALDI TOF-MS (m/z): $1377[\mathrm{M}]^{+}$. $\mathrm{C}_{88} \mathrm{H}_{80} \mathrm{~N}_{8} \mathrm{O}_{8}$ (1377.63): calcd. C 76.72, $\mathrm{H}$ 5.85, $\mathrm{N}$ 8.13; found C 76.68, $\mathrm{H}$ 5.87, $\mathrm{N}$ 8.09.

Cavitand 14: $\mathrm{NMe}_{3} \cdot \mathrm{SO}_{3}$ complex $(68.5 \mathrm{mg}, 0.49 \mathrm{mmol})$ was added to a solution cavitand 13 (63 mg, $0.08 \mathrm{mmol})$ in dry DMF (10 mL). The mixture was stirred under nitrogen atmosphere at $50^{\circ} \mathrm{C}$ for $12 \mathrm{~h}$. An additional portion of $\mathrm{NMe}_{3} \cdot \mathrm{SO}_{3}$ complex (68.5 mg) was added, and the suspension was kept at $50^{\circ} \mathrm{C}$ for another $12 \mathrm{~h}$. The reaction was quenched by addition of water $(10 \mathrm{~mL})$ and $\mathrm{Na}_{2} \mathrm{CO}_{3}$ was added until the $\mathrm{pH}$ reached 7. After concentration, a mixture of methanol/water was added to precipitate the unreacted complex and the salts. After filtration, a mixture of acetone/water was added to the solution to precipitate cavitand $\mathbf{1 4}$ as light pink solid (62 $\mathrm{mg}, 65 \%)$.

${ }^{1} \mathrm{H}$ NMR (D $\left.{ }_{2} \mathrm{O}, 400 \mathrm{MHz}\right): \delta: 1.78\left(\mathrm{~m}, 8 \mathrm{H}, \mathrm{CH}_{2} \mathrm{CH}_{2} \mathrm{CH}_{2}\right) ; 2.51$ (q, 8H, $\mathrm{ArCHCH}_{2}$ ); 4.16 $\left(\mathrm{t}, 8 \mathrm{H}, \mathrm{CH}_{2} \mathrm{CH}_{2} \mathrm{OSO}_{3} \mathrm{Na},{ }^{2} \mathrm{~J}=6.4 \mathrm{~Hz}\right) ; 4.36\left(\mathrm{~d}, 4 \mathrm{H}, \mathrm{CH}_{\text {in }},{ }^{2} \mathrm{~J}=7.8 \mathrm{~Hz}\right) ; 5.8\left(\mathrm{~d}, 4 \mathrm{H}, \mathrm{CH}_{\text {out }}\right.$, $\left.{ }^{2} \mathrm{~J}=7.5 \mathrm{~Hz}\right) ; 6.69\left(\mathrm{~s}, 4 \mathrm{H}, \operatorname{Ar} H_{u p}\right) ; 7.49$ (s, 4H, ArH $\left.H_{\text {down }}\right)$. 
ESI-MS (m/z): $1154[\mathrm{M}-\mathrm{Na}]^{-}, 565[\mathrm{M}-2 \mathrm{Na}]^{2-}, 369[\mathrm{M}-3 \mathrm{Na}]^{3-}, 271[\mathrm{M}-4 \mathrm{Na}]^{4-}$.

Cavitand 15: $\mathrm{NMe}_{3} \cdot \mathrm{SO}_{3}$ complex $(60.5 \mathrm{mg}, 0.43 \mathrm{mmol})$ was added to a solution cavitand 10 (100 mg, $0.07 \mathrm{mmol})$ in dry DMF $(10 \mathrm{~mL})$. The mixture was stirred under nitrogen atmosphere at $50^{\circ} \mathrm{C}$ for $12 \mathrm{~h}$. An additional portion of $\mathrm{NMe}_{3} \cdot \mathrm{SO}_{3}$ complex (60.5 mg) was added, and the suspension was kept at $50^{\circ} \mathrm{C}$ for another $12 \mathrm{~h}$. The reaction was quenched by addition of water $(10 \mathrm{~mL})$ and $\mathrm{Na}_{2} \mathrm{CO}_{3}$ was added until the $\mathrm{pH}$ reached 7. After concentration, a mixture of methanol/water was added to precipitate the unreacted complex and the salts. After filtration, a mixture of acetone/water was added to the solution to precipitate cavitand $\mathbf{1 5}$ as light brown solid (40 mg, 31\%).

${ }^{1} \mathrm{H}$ NMR ([D 6 DMSO, $\left.300 \mathrm{MHz}\right): \delta=8.64(\mathrm{~d}, 8 \mathrm{H}, \mathrm{XX}$ ' part of system AA'XX', $\left.H_{o P y},{ }^{3} \mathrm{~J}=5.9 \mathrm{~Hz}\right) ; 7.90\left(\mathrm{bd}, 8 \mathrm{H}, \mathrm{BB}^{\prime}\right.$ part of system AA'BB', $\left.{ }^{3} \mathrm{~J}=8.1 \mathrm{~Hz}\right) ; 7.85(\mathrm{~m}, 12 \mathrm{H}$, $\mathrm{AA}^{\prime}$ part of system $\left.\mathrm{AA}^{\prime} \mathrm{BB}^{\prime}+\mathrm{Ar} H_{\text {down }}\right) ; 7.70\left(\mathrm{~d}, 8 \mathrm{H}, \mathrm{AA}^{\prime}\right.$ part of system $\mathrm{AA}^{\prime} \mathrm{XX}$, $\left.H_{m P y},{ }^{3} \mathrm{~J}=5.9 \mathrm{~Hz}\right) ; 6.93\left(\mathrm{~s}, 4 \mathrm{H}, \operatorname{Ar} H_{u p}\right) ; 5.57(\mathrm{~s}, 4 \mathrm{H}, \mathrm{OCHO}) ; 4.81\left(\mathrm{t}, 4 \mathrm{H}, \operatorname{ArCH},{ }^{3} \mathrm{~J}=8.0\right.$ $\mathrm{Hz}) ; 3.87\left(\mathrm{bm}, 8 \mathrm{H}, \mathrm{CH}_{2} \mathrm{OSO}_{3} \mathrm{Na}\right) ; 2.56\left(\mathrm{~m}, 8 \mathrm{H}, \mathrm{ArCHCH}_{2}\right) ; 1.64\left(\mathrm{~m}, 8 \mathrm{H}, \mathrm{CH}_{2} \mathrm{CH}_{2} \mathrm{CH}_{2}\right)$. ESI-MS (m/z): $1767[\mathrm{M}-\mathrm{Na}]^{-}, 872[\mathrm{M}-2 \mathrm{Na}]^{2-}, 573[\mathrm{M}-3 \mathrm{Na}]^{3-}, 424[\mathrm{M}-4 \mathrm{Na}]^{4-}$. $\mathrm{C}_{88} \mathrm{H}_{72} \mathrm{~N}_{4} \mathrm{Na}_{4} \mathrm{O}_{24} \mathrm{~S}_{4}(1789.74)$ : calcd. $\mathrm{C} 59.06, \mathrm{H} 4.05, \mathrm{~N} 3.13$; found $\mathrm{C} 58.97, \mathrm{H} 4.16$, N 3.01.

\section{Acknowledgements}

This study was supported by FIRB "Nanoroganizzazione di molecole ibride inorganiche/organiche con proprietà magnetiche ed ottiche". Instrumental facilities at the Centro Interfacoltà di Misure G. Casnati of the University of Parma were used. 


\section{Captions to figures and schemes:}

Figure 1: Sketch of cage self-assembly

Scheme 1: Reagents and conditions: a) $\mathrm{MsCl}, \mathrm{CH}_{2} \mathrm{Cl}_{2} / \mathrm{Et}_{3} \mathrm{~N}, 0^{\circ} \mathrm{C}, 3 \mathrm{~h}, 91 \%$ b) $\mathrm{NaN}_{3}$, DMF, $70^{\circ} \mathrm{C}, 24 \mathrm{~h}, 52 \%$ c) $\mathrm{PPh}_{3}, \mathrm{THF} / \mathrm{H}_{2} \mathrm{O}, 70^{\circ} \mathrm{C}, 2 \mathrm{~h}, 88 \%$ d) $10 \%$ aq. $\mathrm{HCl}$.

Scheme 2: Reagents and conditions: a) Phthalimide, $\mathrm{PPh}_{3}, \mathrm{DEAD}$, THF, reflux, 5 days, $78 \%$ b) $\mathrm{NH}_{2} \mathrm{NH}_{2}, \mathrm{EtOH}$, reflux, 3 h, $92 \%$ c) $10 \%$ aq. $\mathrm{HCl}$.

Scheme 3: Reagents and conditions: a) $\mathrm{DMA}, \mathrm{K}_{2} \mathrm{CO}_{3}, 80^{\circ} \mathrm{C}, 48 \mathrm{~h}, 30 \%$ b) Phthalimide, $\mathrm{PPh}_{3}$, DEAD, THF, reflux, 5 days, $31 \%$ c) $\mathrm{NH}_{2} \mathrm{NH}_{2}$, EtOH, reflux, 3h, $85 \%$.

Scheme 4: Reagents and conditions: a) $\mathrm{NMe}_{3} \cdot \mathrm{SO}_{3}, \mathrm{DMF}, 50^{\circ} \mathrm{C}, 24 \mathrm{~h}, 65 \%$.

Scheme 5: Reagents and conditions: a) $\mathrm{NMe}_{3} \cdot \mathrm{SO}_{3}, \mathrm{DMF}, 50^{\circ} \mathrm{C}, 24 \mathrm{~h}, 31 \%$. 
${ }^{[1]}$ Gui, X; Sherman, J. C. Chem. Commun. 2001, 2680.

${ }^{[2]}$ Hooley, R. J.; Biros S. M.; Rebek, J. Jr. Angew. Chem. Int. Ed. 2006, 45, 3517.

${ }^{[3]}$ Pinalli, R.; Cristini, V.; Sottili, V.; Geremia, S.; Campagnolo, M. Caneschi, A.; Dalcanale, E. J. Am. Chem. Soc. 2004, 126, 6516, and references cited therein.

${ }^{[4]}$ Kobayashi, K.; Yamada, Y.; Yamanaka, M.; Sei, Y.; Yamaguchi, K. J. Am. Chem. Soc. 2004, 126, 13896, and references cited therein.

${ }^{[5]}$ Fox, O. D.; Dalley, N. K.; Harrison, R. G. J. Am. Chem. Soc. 1998, 120, 7111.

${ }^{[6]}$ Harrison, R. G.; Burrows, J. L.; Hansen, L. D. Chem. Eur. J. 2005, 11, 5881.

${ }^{[7]}$ Menozzi, E.; Pinalli, R.; Speets, E. A.; Ravoo, B. J.; Dalcanale, E.; Reinhoudt, D. N. Chem.-Eur. J. 2004, 10, 2199.

${ }^{[8]}$ Haino, T.; Rudkevich, D. M.; Shivanyuk, A.; Rissanen, K.; Rebek, J. Jr. Chem. Eur. J. 2000, 6, 3797.

${ }^{[9]}$ Mezo, A.. R.; Sherman, J. C. J. Org. Chem. 1998, 63, 6824.

${ }^{[10]}$ Gibb, C. L. D.; Gibb, B. C. J. Am. Chem. Soc. 2004, 126, 11408

${ }^{[11]}$ Tunstad, L. M.; Tucker, J. A.; Dalcanale, E.; Weiser, J.; Bryant, J. A.; Sherman, J. C.; Helgeson, R. C.; Knobler, C. B.; Cram, D. J. J. Org. Chem. 1989, 54, 1305.

${ }^{[12]}$ Roman, E.; Peinador, C.; Mendoza, S.; Kaifer, A.. E. J. Org. Chem. 1999, 64, 2577.

${ }^{[13]}$ Kobayashi, K.; Asakawa, Y.; Kato, Y.; Aoyama, Y. J. Am. Chem. Soc. 1992, 114, 10307.

${ }^{[14]}$ Polat, T.; Mohammadi, M.; Linhardt, R. J. Tetrahedron Lett. 2002, 43, 8047.

${ }^{[15]}$ Fujita, M.; Oguro, D.; Miyazawa, M.; Oka, H.; Yamaguchi, K.; Ogura, K. Nature 1995, 378, 469.

${ }^{[16]}$ The corresponding cavitand having four phosphate groups at the lower rim exhibits the same behaviour: Grassi, M.; Pirondini, L.; Dalcanale E. unpublished results.

${ }^{[17]}$ Gibb, B. C.; Chapman, R. C.; Sherman, J. C. J. Org. Chem. 1996, 61, 1505. 

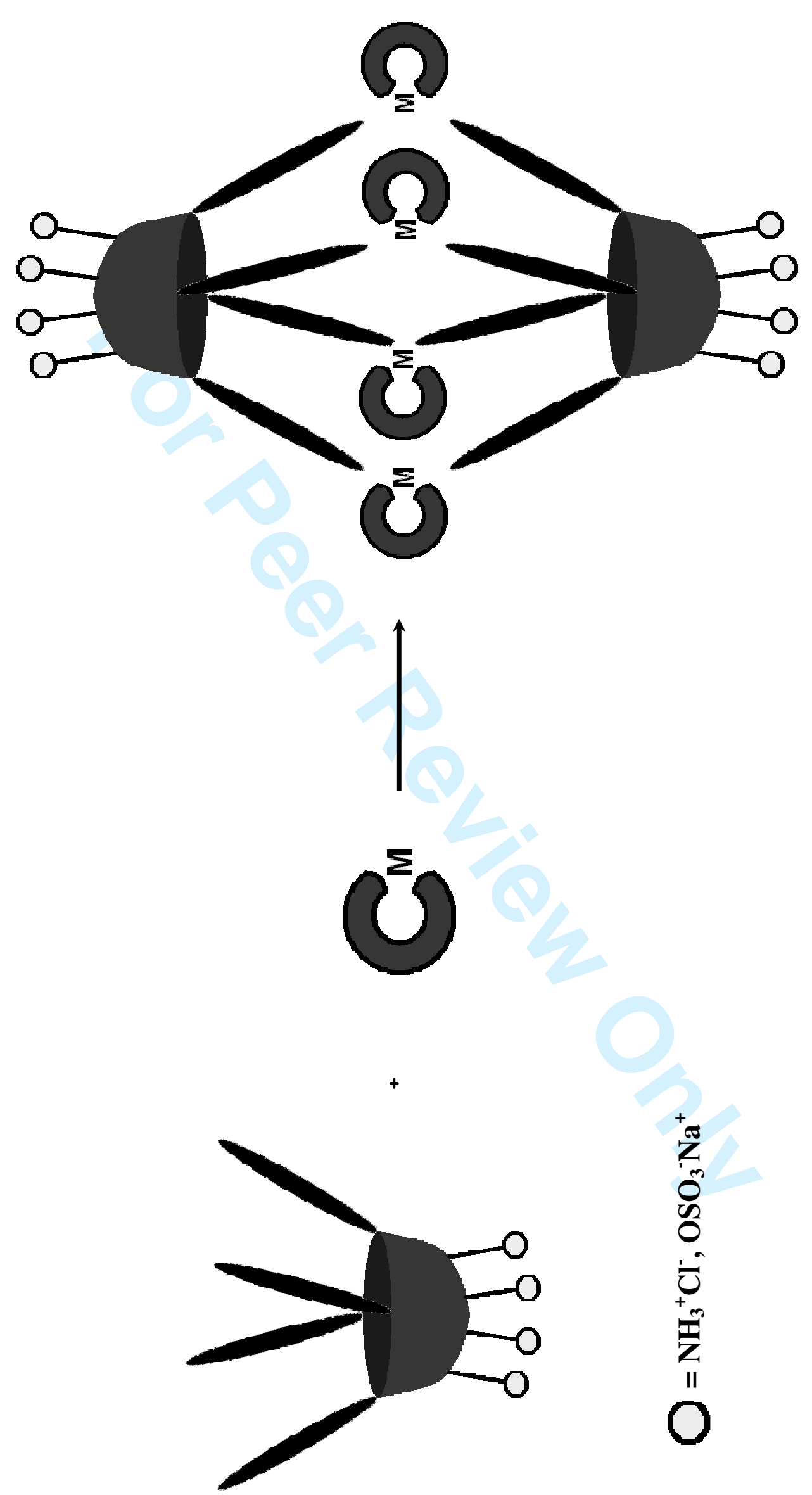